\title{
Histomorphometric changes in the synovial membrane of the knee joint in combined use of the Ilizarov non-free bone plasty and the Masquelet technique (experimental study)
}

\author{
T.A. Stupina ${ }^{1}$, O.V. Diuriagina ${ }^{1}$, D.S. Mokhovikov ${ }^{1}$, Yu.A. Stupina ${ }^{2}$, D.Yu. Borzunov ${ }^{3,4}$ \\ 'Ilizarov National Medical Research Centre for Traumatology and Orthopedics, Kurgan, Russian Federation \\ ${ }^{2}$ Tyumen State Medical University, Tyumen, Russian Federation \\ ${ }^{3}$ Ural State Medical University, Ekaterinburg, Russian Federation \\ 4Central City Clinical Hospital № 23, Ekaterinburg, Russian Federation
}

\begin{abstract}
Relevance Defects of long bones result in anatomical and functional complex of pathologies in the entire limb. There are few fundamental studies of tissues adjacent to bone defects by using different technologies for management of long bone defects. Purpose To study the structural changes in the synovial membrane of the knee joint by modelling the conditions for tibial defect management using the Ilizarov method of non-free bone plasty in combination with the Masquelet technique. Materials and methods The conditions of post-resection defect of the tibia (from $15 \%$ of the segment length) by lengthening the distal fragment were modeled in ten mongrel dogs. Temporarily, for 30 days, a cement spacer was implanted into the post-resection defect gap. Upon its removal, the intermediate fragment in the lower third of the leg was transported at a rate of $1 \mathrm{~mm}$ in 4 steps until complete contact of the bone fragments. Histomorphometric studies of the synovium were carried out at the observation stages at the end of the fixation period (60 days) and after removing the apparatus ( 30 days). Results Two types of changes were revealed in the synovium: changes of a destructive nature without synovitis ( $30 \%$ of cases) and with signs of synovitis ( $70 \%$ of cases, 3 dogs had mild synovitis and 4 dogs had severe synovitis). Changes in the microvessels of the synovial membrane in synovitis indicated impaired microcirculation, high activity of angiogenesis and the development of hypervascularization. Conclusion Experimental management of the tibial bone defect by Ilizarov method in combination with the Masquelet technique revealed signs of synovitis of the knee joint in $70 \%$ of cases using histophorphometry methods.
\end{abstract}

Keywords: synovium, morphometry, lower leg defect, non-free bone plasty, Ilizarov method, Masquelet technique

\section{INTRODUCTION}

Defects of long bones represent a complex of anatomical and functional pathologies in the entire limb. Bone defects are outcomes of a long-lasting disease and result from trauma or failures of surgical interventions. The search for effective methods of treating patients with bone defects remains relevant up to date. A number of studies show that Ilizarov non-free bone grafting is a method of choice, and in some clinical observations it is more effective in comparison with the use of free vascularized bone grafts, especially for large bone defects [1-3]. At the same time, the drawbacks of this technology are associated with the need for a long period of fixation of the limb in the apparatus [4].

Recently, technologies have emerged that open new prospects for solving this problem. According to some authors, the Masquelet technique is a reliable method for treating segmental defects, but it requires an adequate autogenous bone graft [5].

Our experiment tested the method of filling a post-resection tibial defect by the Ilizarov method of non-free bone grafting in combination with the Masquelet technique. It was found that the combination of technologies has an impact on the histological structure of the articular cartilage of the knee joint [6].

Difficulties in the rehabilitation of patients with this nosology are associated with significant concomitant structural and functional disorders in the lower extremity, including persistent limitations of joint mobility; the literature describes cases that subsequently needed arthroplasty $[7,8]$.

Fundamental studies of joint tissues in the course of treating patients with long bone defects with different technologies are rare $[6,9]$.

One of the most significant factors of articular pathology is the inflammatory process in the synovial membrane [10]. However, its changes in the experimental model of filling a post-resection leg defect with the Ilizarov method in combination with the Masquelet technique have not been studied. At the same time, basic research of joint components is necessary for rehabilitation protocols.

Our purpose was to study structural changes in the synovial membrane of the knee joint by simulating the conditions by management of tibial defects using the Ilizarov method of non-free bone grafting in combination with the Masquelet technology.

Based on the previously obtained data on histomorphometric changes in the cartilage of the knee joint [6], we assume that this fundamental study will also have an applied value for the development of protocols and guidelines for complex rehabilitation of patients with long bone defects in the conditions of the combined use of Ilizarov and Masquelet technologies. 


\section{MATERIAL AND METHODS}

The experiment included three steps and was performed on 10 mongrel dogs (body weight averaged $16.8 \pm 0.4 \mathrm{~kg}$, age $3.9 \pm 0.3$ years, leg length from 17 to $20 \mathrm{~cm}$ ). At the first step of the experiment, a defectpseudarthrosis was modeled in the upper third of the tibia in the conditions of transosseous osteosynthesis using the Ilizarov apparatus (patent No. 2539627 RF) [11]. The period of fixation of the segment in the apparatus was 60 days. At the second step of the experiment, the pseudoarthrosis zone was subjected to dosed distraction in order to form a defect of at least $15 \%(2.5 \mathrm{~cm})$ of the segment length. Then a cement spacer was placed into the gap, creating a tight bonespacer-bone contact. After 30 days, the implant was removed. After transverse osteotomy in the lower third of the tibia, distraction started 7 days later by means of dosed and discrete fragment transport by $1 \mathrm{~mm}$ in 4 doses for 25-28 days until the intermediate bone fragment reached full contact with the opposite bone fragment. The apparatus was dismantled after 60 days. Study time-points: 60 days of fixation $(n=5)$ and 30 days after removal of the apparatus $(n=5)$.

The study was carried out in accordance with the European Convention for the Protection of Vertebrate Animals and Directive 2010/63 / EU of the European Parliament and the Council of the European Union on the protection of animals used for scientific purposes, in accordance with SP 2.2.1.3218-14; GOST 332172014; GOST 33215-2014, as well as approved by the institutional ethical committee (protocol No. 2 (57) dated 17/05/18).

For histomorphometric study, synovial samples were excised from the suprapatellar zone. After aldehyde and osmium fixation, they were dehydrated and embedded in resin. Semi-thin $(0.5-1.0 \mu \mathrm{m})$ sections obtained with a Nova ultratome (LKB, Sweden) were stained with methylene blue and basic fuchsin. Microscopy, digitization, and quantitative studies were performed using an AxioScope.A1 microscope supplied with an AxioCam digital camera and Zenblue software (CarlZeissMicroImaging GmbH, Germany). The thickness of the inner layer of the synovial membrane was measured ( $\mu \mathrm{m}, \mathrm{M} \pm \sigma$ ), and the numerical density of microvessels $(\mathrm{M} \pm \sigma)$ in $1 \mathrm{~mm}^{2}$ was calculated. The severity of synovitis was assessed using the V. Krenn et al system (2006) [12]. Control samples were synovium of the knee joint of intact animals $(n=5)$.

The digital material was processed using descriptive statistics. The statistical significance of differences was determined using the nonparametric Wilcoxon test at a significance level (p) of 0.05 . The calculations were performed using the AtteStat program, version 9.3.1.

\section{RESULTS}

Light microscopy of the synovium after 60 days of fixation revealed two types of changes.

In three animals out of five, relative to the control group, there was a decrease in the thickness of the inner layer, $19.91 \pm 2.51 \mu \mathrm{m}(\mathrm{p}<0.05)$, and in the numeric density of the vessels of the microvasculature in the superficial collagen-elastic subsynovial layer, $298.05 \pm 26.74(\mathrm{p}<0.05)$. In the control group, these indicators were $26.08 \pm 2.04 \mu \mathrm{m}$ and $335.05 \pm 28.88$,

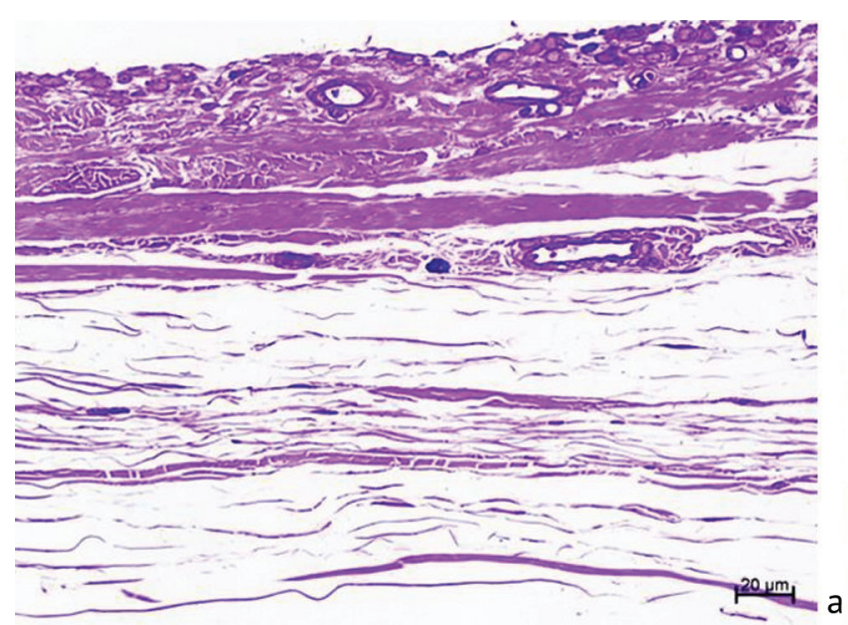

respectively. Synovial cells, predominantly of the fibroblastic type, were positioned in 1-2 layers (Fig. 1). In the superficial collagen-elastic layer, normal cellularity was preserved, collagen fibers prevailed. Signs of edema were recorded, fiber disruption and sparse arrangement of collagen fibers, an increase in optical space between the fibers (Fig. 1a). The semiquantitative synovitis score was one point, which indicated its absence.

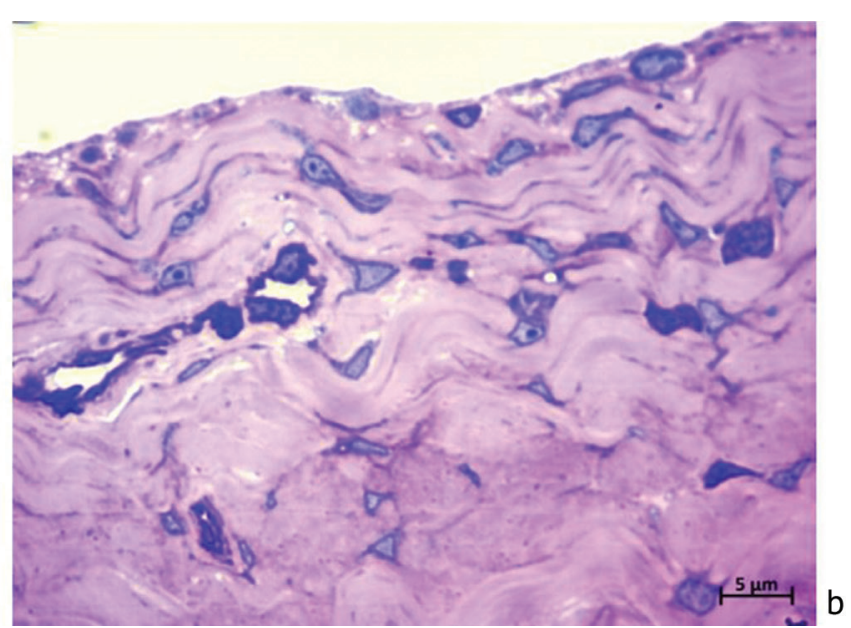

Fig. 1 Synovial membrane after 60 days of fixation: $\boldsymbol{a}$ thinning of the inner layer, optical spaces between the fibers of the subsynovial layer (magnification $200 \times$ ); $\boldsymbol{b}$ fibroblastic synoviocytes in the inner layer (magnification $1000 \times$ ). Stained with methylene blue and basic fuchsin 
Two animals at this time-point of the experiment, on the contrary, had focal hyperplasia of the inner layer; its thickness was $46.43 \pm 3.14 \mu \mathrm{m}(\mathrm{p}<0.05)$, and hypervascularization of the subsynovial layer. The numerical density of the vessels of the microvasculature exceeded the controls by 1.7 times, $597.89 \pm 36.14(\mathrm{p}<0.05)$. Synovial cells were positioned in 5-6 layers, macrophage-type synoviocytes dominated. Such synoviocytes were larger in size, had outgrowths; the cytoplasm was vacuolated and contained granular inclusions. Foci of an inflammatory infiltrate, consisting of numerous lymphocytes and plasma cells, were detected (Fig. 2).

Signs of lipomatosis were visualized in the subsynovial layer; cellularity was moderately increased; perivascular mast cells and plasma cells were noted. A semiquantitative assessment of synovitis was 7 points and indicated severe synovitis.

In all observations, microvessels were detected, the walls of which were thickened; the swollen nuclei of endothelial cells overlapped the intravascular space.

Amonth after dismantling the apparatus, the animals differed in the severity of synovitis as in the previous period of the experiment. Three dogs had V. Krenn et

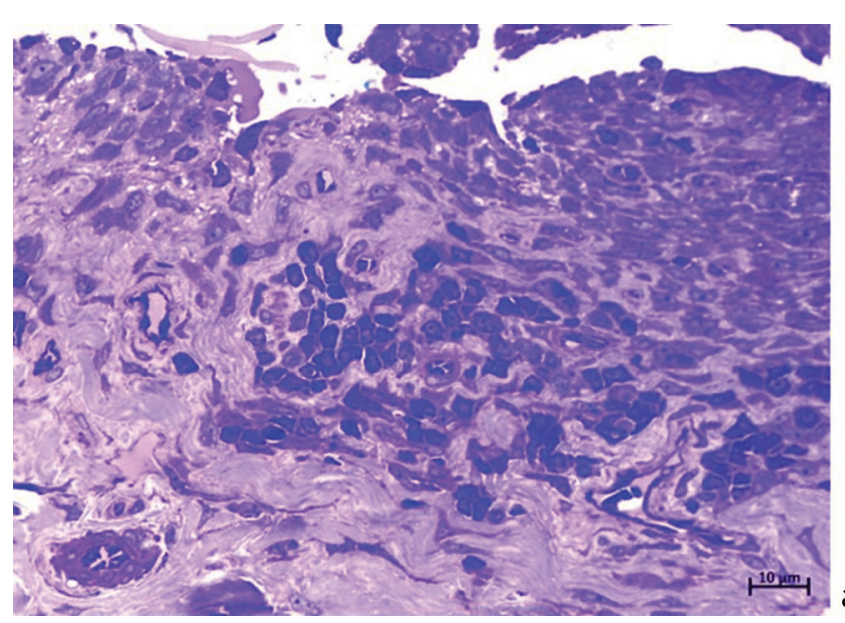

al score [12] of two points, which corresponds to mild synovitis. The histological structure of the synovial membrane was similar to the structure of the synovium without synovitis after 60 days of fixation, with the exception of the presence of macrophage synoviocytes in the inner layer and slightly increased cellularity in the subsynovial layer due to mast cells (Fig. 3a). The thickness of the inner layer was comparable to the control animals, $25.69 \pm 2.63 \mu \mathrm{m}(\mathrm{p}>0.05)$, the numeric density of microvessels slightly exceeded the one in the control group, $376.93 \pm 43.66(\mathrm{p}>0.05)$.

Two dogs had V. Krenn et al score [12] of 5 points, which indicates pronounced synovitis. The thickness of the inner layer retained increased values, $49.95 \pm 4.23 \mu \mathrm{m}(\mathrm{p}<0.05)$, the numerical density of microvessels was 2 times higher than in the controls, $636.89 \pm 41.39(\mathrm{p}<0.05)$.

Compared to the synovial membrane with pronounced synovitis after 60 days of fixation, the number of synovial cells layers (2-3 layers) and the representation of macrophage synoviocytes in the inner layer were reduced; the inflammatory infiltrate consisted of lymphocytes and plasma cells and was mainly diffused (Fig. 3 b ).

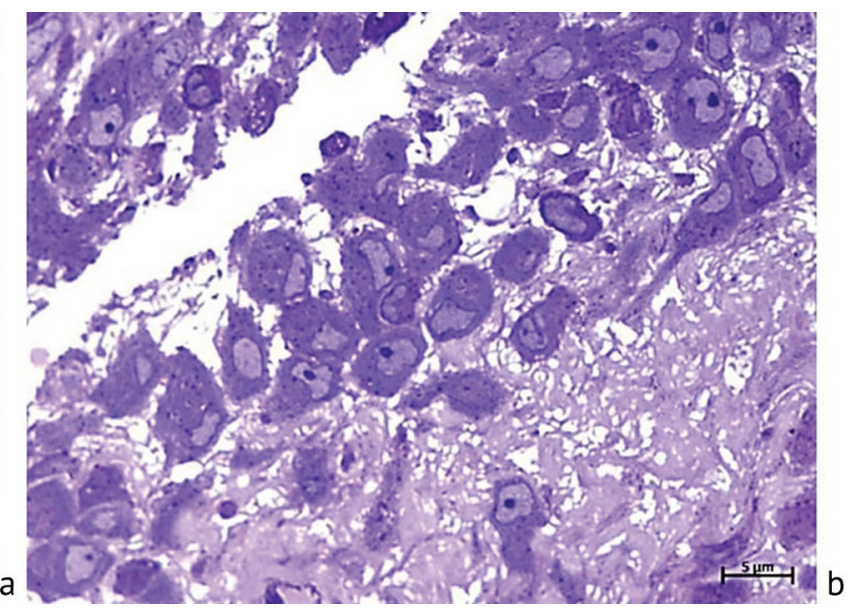

Fig. 2 Synovitis after 60 days of fixation: $\boldsymbol{a}$ moderate hyperplasia of the inner layer, foci of lymphoplasmatic cell infiltration (magnification $400 \times$ ); $\boldsymbol{b}$ macrophage synoviocytes in the inner layer (magnification $1000 \times$ ). Stained with methylene blue and basic fuchsin
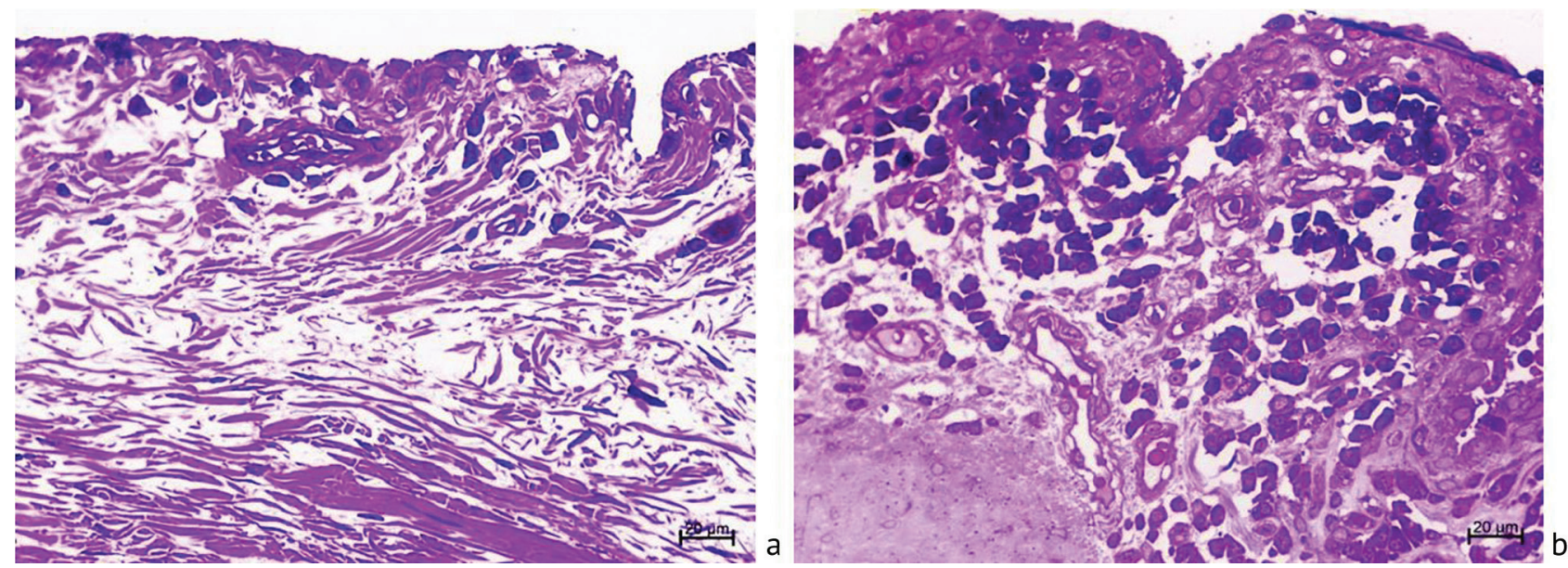

Fig. 3 Synovial membrane at 30 days after removing the apparatus: $\boldsymbol{a}$ mild synovitis, solitary plasmatic cells in the subsynovial layer; $\boldsymbol{b}$ pronounced synovitis, inflammatory infiltrate of a diffuse type. Stained with methylene blue and basic fuchsin; magnification $200 \times$ 
Similar to 60 days of fixation, microvessels with an obliterated lumen or stenosis were observed in all animals, the walls of the vessels were hypertrophied.

\section{DISCUSSION}

The synovium makes a significant contribution to the condition of the articular cartilage [13]. Previous studies with experimental lengthening of the tibia revealed reactive and/or destructive-reparative changes in the articular cartilage of the knee joint, the severity of which correlated with changes in the synovial membrane [14-16].

It could be assumed that the synovial membrane does not affect the morphological structure of the articulating surfaces of the knee joint by performing osteoplastic interventions under the conditions of transosseous osteosynthesis. This assumption is based on the fact that the length of the bone segment is preserved by management of a post-resection defect with the Ilizarov method of non-free bone grafting in combination with the Masquelet technology. Indeed, in this model, the length of the segment with the defect was the same in relation to the contralateral segment.

However, the study revealed two types of changes in the synovial membrane of the knee joint. Those were changes of a destructive nature without synovitis in $30 \%$ of cases and with signs of synovitis in $70 \%$ of cases including hyperplasia of the integumentary layer, presence of an inflammatory infiltrate, hypervascularization (mild synovitis in three dogs and pronounced synovitis in four dogs).

Changes in the vessels of the synovial membrane microvasculature in synovitis prove microcirculation disorders, high activity of angiogenesis and the development of hypervascularization, what is prognostically unfavorable for the restoration of joint function [17].
Signs of synovitis in inflammatory processes (rejection of the inner layer, proliferation of synoviocytes of the inner layer up to 10 or more rows, polypous hyperplasia of villi, formation of lymphoid follicles, neutrophils [18]) were not identified in this experiment.

Most likely, biomechanical factors were the initiator of such changes in the synovium. It is known that in posttraumatic synovitis, pathomorphological signs are manifested by hyperplasia of the inner layer and, to a lesser extent, by proliferation of synoviocytes and focal inflammatory infiltration [19].

In our earlier studies, all animals showed signs of denervation changes and ischemia of the tibialis anterior muscle; microcirculatory disorders, destruction and decrease in the number of nerve fibers were recorded in the peroneal nerves, which was associated with the multistage and duration of the experimental study [20].

It is known that the state of the synovium in joint pathology correlates with destructive processes in the articular cartilage and clinical signs of the pathological process manifestation [21, 22]. This determines the significance of histological studies of changes in the synovium in clinical pathology and in experimental practice.

Structural changes in the synovial membrane have an impact on the processes of destruction of the articular cartilage [23]. In this experiment, in our earlier studies on dogs with severe synovitis, synovial pannus was noted on the articular surface [6].

\section{CONCLUSION}

The experimental management of a tibial defect by fragment bone transport with the Ilizarov method in combination with the Masquelet

method revealed signs of knee joint synovitis in $70 \%$ of cases detected with histomorphometry methods.

\section{Conflict of interests: none}

This study was supported by the program of the Ministry of Health of the Russian Federation within the framework of the state assignment of the Federal State Budgetary Institution Ilizarov NMITs for TO on research work for 2018-2020.

\section{REFERENCES}

1. Lasanianos N.G., Kanakaris N.K., Giannoudis P.V. Current management of long bone large segmental defects. Orthopaedics and Trauma, 2010, vol. 24, no. 2, pp. 149-163. DOI: https://doi.org/10.1016/j.mporth.2009.10.003

2. Barabash A.P., Kesov L.A., Barabash Iu.A., Shpiniak S.P. Zameshchenie obshirnykh diafizarnykh defektov dlinnykh kostei konechnostei [Restoration of extensive shaft defects of limb long bones]. Travmatologiia i Ortopediia Rossii, 2014, no. 2, pp. 93-99. (in Russian)

3. Bari M.M., Shahidul Islam, Shetu N.H., Mahfuzer R.M. Rekonstruktsiia diafizarnykh defektov bolshebertsovykh kostei po metodu G.A. Ilizarova [Reconstruction of bone loss of diaphyseal tibial bones using G.A. Ilizarov technique]. Genij Ortopedii, 2015, no. 2, pp. 17-20. (in Russian)

4. Shastov A.L., Kononovich N.A., Gorbach E.N. Problema zameshcheniia posttravmaticheskikh defektov dlinnykh kostei v otechestvennoi travmatologo-ortopedicheskoi praktike (obzor literatury) [Management of posttraumatic long bone effects in the national orthopedic practice (literature review)]. Genij Ortopedii, 2018, vol. 24, no. 2, pp. 252-257. DOI: 10.18019/1028-4427-2018-24-2-252-257 
5. Lu Y., Ma T., Ren C., Li Z., Sun L., Xue H., Li M., Zhang K., Zhang C., Wang Q. Treatment of segmental tibial defects by bone transport with circular external fixation and a locking plate. J. Int. Med. Res., 2020, vol. 48, no. 4, 300060520920407. DOI: 10.1177/0300060520920407

6. Stupina T.A., Diuriagina O.V., Emanov A.A., Mokhovikov D.S., Borzunov D.Yu. Patomorfologiia sustavnogo khriashcha kolennogo i zapliusnevogo sustavov pri eksperimentalnom zameshchenii postrezektsionnogo defekta goleni metodom Ilizarova $\mathrm{v}$ kombinatsii s tsementnym speiserom [Pathomorphology of articular cartilage of the knee and ankle joints in experimental repair of postresection tibial defect using the Ilizarov method and cement spacer]. Genij Ortopedii, 2020, vol. 26, no. 3, pp. 398-402. DOI: 10.18019/1028-4427-2020-26-3-398-402

7. Prokhorova E.S., Urazgildeev R.Z., Eremushkin M.A., Kolyshenkov V.A. Sovremennye podkhody k lecheniiu patsientov s lozhnymi sustavami i defektami dlinnykh kostei nizhnikh konechnostei: analiticheskii obzor [Modern approaches to treatment of patients with pseudoarthroses and defects of the lower limb long bones: an analytical review]. Vestnik Vosstanovitelnoi Meditsiny, 2020, vol. 96, no. 2, pp. 84-89. (in Russian) DOI: 10.38025/ 2078-1962-2020-96-2-84-89

8. Giotikas D., Tarazi N., Spalding L., Nabergoj M., Krkovic M. Results of the Induced Membrane Technique in the Management of Traumatic Bone Loss in the Lower Limb: A Cohort Study. J. Orthop. Trauma, 2019, vol. 33, no. 3, pp. 131-136. DOI: 10.1097/BOT.0000000000001384

9. Emanov A.A., Stupina T.A., Borzunov D.Y., Shastov A.L. Osobennosti strukturnoi reorganizatsii sustavnogo khriashcha i sinovialnoi obolochki kolennogo sustava pri zameshchenii postrezektsionnogo defekta kostei goleni $\mathrm{v}$ usloviiakh chreskostnogo osteosinteza apparatom Ilizarova $\mathrm{v}$ eksperimente [Peculiar features of structural reorganization of the articular cartilage and synovium of the knee when filling a postresection defect of the leg bones under transosseous osteosynthesis with the Iliizarov fixator experimentally]. Mezhdunarodnyi Zhurnal Prikladnykh $i$ Fundamentalnykh Issledovanii, 2015, no. 12-7, pp. 1228-1232. (in Russian)

10. Mustafaev N.R., Liubarskii M.S., Bgatova N.P., Shumkov O.A. Morfologicheskie aspekty sostoianiia mikrotsirkuliatsii i limfaticheskogo drenazha v sinovialnoi obolochke kolennogo sustava u patsientov s razlichnymi stadiiami gonartroza [Morphological aspects of microcirculation and lymphatic drainage condition in the knee synovium of patients with different stages of gonarthrosis]. Biulleten VSNTS SO RAMN, 2011, no. 3 (79), pp. 81-85. (in Russian)

11. Emanov A.A., Gorbach E.N., Mitrofanov A.N. Sposob modelirovaniia defekt-psevdoartroza kosti konechnosti [The way of modeling defectpseudoarthrosis of the limb bone]. Patent RF no. 2539627 G09B 23/28, 2013. (in Russian)

12. Krenn V., Morawietz L., Burmester G.R., Kinne R.W., Mueller-Ladner U., Muller B., Haupl T. Synovitis score: discrimination between chronic lowgrade and high-grade synovitis. Histopathology, 2006, vol. 49, no. 4, pp. 358-364. DOI: 10.1111/j.1365-2559.2006.02508.x

13. Borodin Iu.I., Liubarskii M.S., Bgatova N.P., Mustafaev N.R., Dremov E.Iu. Morfologicheskie kriterii sostoianiia mikrotsirkuliatsii i limfaticheskogo drenazha $\mathrm{v}$ sinovialnoi obolochke kolennogo sustava $\mathrm{v}$ norme i pri patologii [Morphological criteria of microcirculation and lymphatic drainage condition in the knee synovium normally and in case of pathology]. Morfologiia, 2008, vol. 133, no. 1, pp. 51-55. (in Russian)

14. Stupina T.A., Shchudlo N.A., Petrovskaia N.V., Stepanov M.A. Gistomorfometricheskii analiz sustavnogo khriashcha i sinovialnoi obolochki kolennogo sustava pri metadiafizarnom udlinenii goleni [The histomorphometrical analysis of the articular cartilage and synovium of the knee for meta-diaphyseal lengthening of the leg]. Travmatologiia i Ortopediia Rossii, 2013, no. 1 (67), pp. 80-86. (in Russian)

15. Stupina T.A., Shchudlo M.M., Shchudlo N.A. [Changes in the knee joint synovial membrane and articular cartilage during shin lengthening by autodistractor at increased daily rate]. Morfologiia, 2013, vol. 143, no. 3, pp. 66-70. (in Russian)

16. Stupina T.A., Shchudlo M.M., Shchudlo N.A., Stepanov M.A. Histomorphometric analysis of knee synovial membrane in dogs undergoing leg lengthening by classic Ilizarov method and rapid automatic distraction. Int. Orthop., 2013, vol. 37, no. 10, pp. 2045-2050. DOI: 10.1007/s00264-013-1919-0

17. Silverman M.D., Haas C.S., Rad A.M., Arbab A.S., Koch A.E. The role of vascular cell adhesion molecule 1/ very late activation antigen 4 in endothelial progenitor cell recruitment to rheumatoid arthritis synovium. Arthritis Rheum., 2007, vol. 56, no. 6, pp. 1817-1826. DOI: 10.1002/art.22706

18. Gerasimenko M.A., Pashkevich L.A., Mokhammadi M.T., Tretiak S.I., Zhuk E.V. Morfologicheskie kriterii differentsialnoi diagnostiki sinovitov kolennogo sustava revmatoidnogo geneza u detei i podrostkov [Morphological criteria of differential diagnosis of the knee synovites of rheumatoid genesis in children and adolescents]. Meditsinskii Zhurnal, 2013, no. 1 (43), pp. 63-67. (in Russian)

19. Grigorovskii V.V., Silchenko V.P., Grigorovskaia A.V. Gistologicheskoe stroenie, kletochnyi sostav i kliniko-morfologicheskaia differentsialnaia diagnostika sinovialnoi gigantokletochnoi opukholi diffuznogo tipa [Histological structure, cellular composition, and clinical-morphological differential diagnosing synovial giant-cell tumor of diffuse type]. Onkologiia, 2015, vol. 17, no. 2, pp. 119-128. (in Russian)

20. Mokhovikov D.S., Stupina T.A., Varsegova T.N., Diuriagina O.V., Emanov A.A., Borzunov D.Yu. Gistomorfometricheskie kharakteristiki perednei bolshebertsovoi myshtsy i malobertsovogo nerva pri eksperimentalnom zameshchenii postrezektsionnogo defekta goleni apparatom Ilizarova $\mathrm{v}$ kombinatsii s metodom Masquelet [Histomorphometric characteristics of the tibialis anterior muscle and the peroneal nerve in experimental repair of post-resection tibial defect using the Ilizarov external fixation and the Masquelet technique]. Genij Ortopedii, 2020, vol. 26, no. 2, pp. $216-221$. DOI: $10.18019 / 1028-4427-2020-26-2-216-221$

21. Pavlova V.N., Pavlov G.G., Shostak N.A., Slutskii L.I. Sustav: morfologiia, klinika, diagnostika, lechenie [Joint: morphology, clinical picture, diagnosis, treatment]. M., Meditsinskoe Informatsionnoe Agentstvo, 2011, 549 p. (in Russian)

22. Makushin V.D., Stupina T.A. K voprosu ob aktivizatsii protsessov, reguliruiushchikh vosstanovlenie struktury sustavnogo khriashcha (obzor literatury i sobstvennye dannye) [To the problem of activating the processes regulating articular cartilage structure recovery (Review of literature and our own data]. Genij Ortopedii, 2014, no. 1, pp. 82-88. (in Russian)

23. Vidinov N., Djerov A. Ultrastructural changes in the transitional zone between articular cartilage and synovial membrane during the development of experimental osteoarthrosis. Int. Orthop., 2002, vol. 26, no. 3, pp. 137-140. DOI: 10.1007/s00264-002-0340-x

Received: 18.12 .2020

\section{Information about the authors:}

1. Tatyana A. Stupina, Ph.D. of Biological Sciences,

Ilizarov National Medical Research Centre for Traumatology and Orthopedics, Kurgan, Russian Federation,

Email: StupinaSTA@mail.ru

2. Olga V. Diuriagina, Ph.D. of Veterinary Sciences,

Ilizarov National Medical Research Centre for Traumatology and Orthopedics, Kurgan, Russian Federation,

Email: diuriagina@mail.ru

3. Denis S. Mokhovikov, M.D., Ph.D.,

Ilizarov National Medical Research Centre for Traumatology and Orthopedics, Kurgan, Russian Federation

4. Yulia A. Stupina,

Tyumen State Medical University, Tyumen, Russian Federation,

Email: yulya.stupina.2000@mail.ru

5. Dmitry Yu. Borzunov, M.D., Ph.D.,

Ural State Medical University, Ekaterinburg, Russian Federation,

Central City Clinical Hospital № 23, Ekaterinburg, Russian Federation,

Email: borzunov@bk.ru 